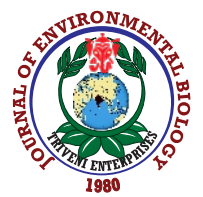

\title{
Degradation ability of wood decay fungi in teak (Tectona grandis L.) wood under storage condition
}

\author{
A. Sudha ${ }^{1 *}$, G. Thiribhuvanamala ${ }^{2}$ and S. Rajamanickam ${ }^{3}$ \\ Department of Plant Pathology, Tamil Nadu Agricultural University, Coimbatore-641 003, India \\ *Corresponding Author Email : sudhaa1981@gmail.com
}

\begin{abstract}
Aim: The present study was undertaken to provide basic knowledge about the teak woody biomass degradation ability of wood decay fungi.

Methodology: Wood decay fungi was isolated from the decayed wood samples collected from teak wood logs. The weight loss of teak wood and moisture content were assessed under in-vitro condition by incubating the teak wood block with the isolated fungi. Further, the secretion of ligninolytic enzymes viz., laccase, lignin peroxidise (LiP) and manganese peroxidase (MnP) produced by wood decay fungi were assessed to understand their degrading ability.
\end{abstract}

Results: Wood decay fungi namely, Daldinia concentrica, Ganoderma lucidum, Lenzites betulina, Ganoderma tsugae, Trametes versicolor and Schizophyllum commune, were isolated from teak wood logs as pure culture and were used for studying their degrading ability. Higher degrading percentage of 10.50 and 12.0 was recorded with $L$. betulina and $T$. versicolor inoculated wood blocks on $60^{\text {th }}$ day of incubation. Similarly, the maximum moisture content of 54.45 and 50.00 percent was recorded with $L$. betulina and $T$. versicolor at $60^{\text {th }}$ day of incubation in teak wood blocks. Supporting these results, L. betulina showed increased secretion of laccase, LiP and MnP enzyme activity to the level of $0.60,0.056$ and $0.26 \mathrm{U} \mathrm{ml} \mathrm{l}^{-1}$, respectively.

Interpretation: The results of the present study gives an understanding on the degrading ability of wood decay fungi which can be used to devise integrated management practices to minimise the losses under storage.

Key words: Ligninolytic enzyme activity, Teak wood, Tectona grandis, White-rot fungi

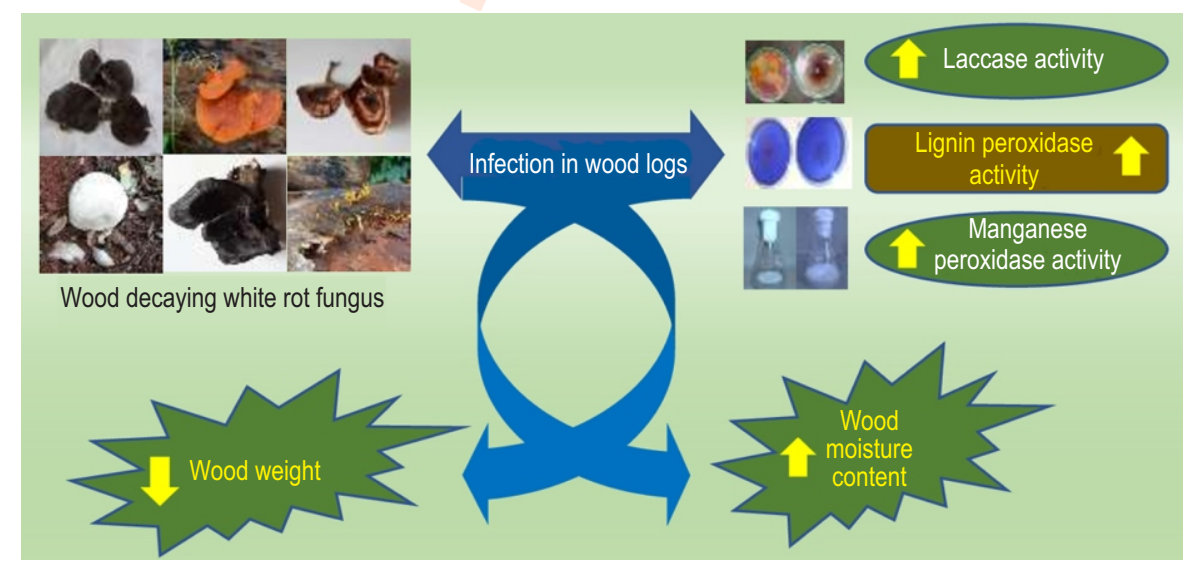

How to cite : Sudha, A., G. Thiribhuvanamala and S. Rajamanickam: Degradation ability of wood decay fungi in teak (Tectona grandis L.) wood under storage condition. J. Environ. Biol., 42, 982-987 (2021). 


\section{Introduction}

Teak (Tectona sp.), a hardwood tree belonging to family Lamiaceae, is found as common forest vegetation comprising of three species, namely Tectona hamiltoniana, T. philippinensis and T. grandis (Wikipedia, 2010). Among these, T. grandis is the most widely cultivated hardwood timber species in India . Though saw dust and sap from teak species showed antimicrobial activity against several pathogens, the wood is infected by several fungal pathogens during growth and storage in saw mills (Amadi and Saka, 2011). Most of the timber-degrading fungal pathogens belong to order Aphyllophorales are economically important as pathogens of forest trees causing enormous damage. However, these wood-rotting fungi are also important in the forest ecosystem as they are active decomposers of organic matter (Natrajan and Kolandavelu, 1998). They can be valuable resources for few pharmaceuticals, food production, bioremediation of toxic chemical spills (Kirk et al., 1992a), biopulping, dye and other industrial uses (Akhtar et al., 1993; Kirk et al., 1992b; Mendonça et al., 2008).

Deforestation, fire and diseases have resulted in loss of forest area cover between 12 and 15 million ha/year in the 1990s (Matthews, 2001). At present, the total forest area is decreasing due to felling of trees. Moreover, felled trees and wood logs left in the field for longer periods are conducive to infection by wood rot pathogens. Inferior quality of wood blogs have been reported in economically important trees like teak, sal and rose wood affected by wood rotting fungi. Timber decay is caused primarily by the enzymatic activities of microorganisms. Fungi degrade all major wood components (cellulose, hemicellulose and lignin) more or less simultaneously, so that the wood becomes more fragile, but remains white as the decay progresses. White rots are caused by major root rot pathogens of trees, viz., G. lucidum, L. betulina, S. commune and also by many saprotrophic fungi including the common colonizers of stumps Coriolus versicolor and the common wood rotting members of Ascomycota (Xylaria hypoxylon and $X$. polymorpha). These pathogens are left unnoticed in the forest plantations because of less awareness. After felling trees, wood logs are left as such in the forest itself without immediate transport to the storage yard.

During this period, due to favourable environmental conditions, the pathogen progresses deep inside the wood. Such woods are unnoticed and they are brought to the storage yard where proper humidity is not maintained, and the growth of the pathogen inside the wood logs, remains unnoticed. When infested woods are used in the market, the quality of material is degraded by the wood rotting fungi unnoticed. These degraded materials, which converted into commercial furniture, have poor quality and cause huge losses to timber growers (Nagadesi et al., 2013). Most of the wood decay fungi belong to white rot basidiomycetes and are considered as an interesting group of fungi, owing to their ability to accommodate even detrimental conditions of the environment where they continue to act as natural lignocellulose destroyers by employing an oxidative process mediated by a unique set of extracellular enzyme system comprising of three major classes of enzymes designated as lignin peroxidase (LiP), Manganese peroxidase $(\mathrm{MnP})$ and Laccase (Lac) (Ryu et al., 2003; Couto, 2009; Patrick et al., 2010). However two or more enzymes may be produced simultaneously by one type of white rot/ wood decay fungi which again depends on the $\mathrm{pH}$ of wood, type of wood and its composition, temperature and relative humidity conditions. White rot basidiomycetes fungi are considered as "wood decaying machinery" due to lignocellulolytic enzymes, organic acids, organohalogen metabolites, reactive oxygen species, etc., that make the fungi to mineralize the components of wood (Manavalan et al., 2015; Xu et al., 2015; Gahlout et al., 2017). The progression of wood decay is closely correlated to the occurrence and ecological functions of fungi, climate change, intensity of wood breakdown, virulence nature of fungi, changes in the diversity of associated biota, progressions of nutrient transformations, and other processes (Marcot, 2017.) Although wood decay fungi are excellent degraders in forest ecosystem and play a pivotal role in recycling nutrients in a forest ecosystem, their role in deterioration of wood under storage needs to be studied. Hence, this study was conducted to understand the secretion of lignolytic enzymes and degrading ability of wood decay fungi.

\section{Materials and Methods}

Collection and isolation of wood rotting pathogens: Logs of wood showing typical rot symptoms were collected from the forest area at Mettupalayam, storage yards and saw mills from Coimbatore district, Tamil Nadu from October 2017 to January 2019. The specimens were conveniently collected in paper bags and the pathogens were isolated on PDA medium from rotted tissue as suggested by Rangaswami (1958). Pure culture of fungi was sub-cultured in PDA slants and refrigerated at $4^{\circ} \mathrm{C}$ for further use. The pathogens were identified based on the micro and morphological keys provided by the Directorate of Mushroom Research, Solan and on the basis of a key proposed by Stalpers (1978).

Assessing pathogenicity and decay potential: The isolated fungal pathogens were inoculated separately on teak wood to assess the virulence and decay potential of wood decaying fungi as described by Lekounougou et al. (2008). Oven-dried teak woodblocks of $2.5 \times 2 \times 0.5 \mathrm{~cm}$ size were prepared from outer heartwood (adjacent to sapwood) without knots, visible decay and stains. Each wood block was then weighed, four woodblocks were kept in each conical flask and sterilized in an autoclave for 2 hr under $15 \mathrm{lb}$ pressure. Pure culture of fungal pathogens was maintained in $9 \mathrm{~mm}$ discs and were inoculated separately into sterilized wood blocks and incubated at $26 \pm 2^{\circ} \mathrm{C}$ for 60 days. Each pathogen was kept in three replicates and the control was also maintained as sterilized woodblocks without any pathogen inoculation. Sampling was done at 15-day-interval to assess the decay potential of wood decaying fungi. On sampling, the woodblocks were taken out from the flasks and the superficial fungal mycelia on the wood blocks were carefully scraped off 
without causing any damag. The weight and moisture loss due to wood decay was measured and compared. The experiment was replicated four times and statistically analysed by completely randomized design.

Assessment of weight loss: Wood decay was measured as the percentage loss of wood weight after the fungal inoculation test. Weight loss was measured after drying each sample. At different incubation times, colonized wood blocks were carefully removed, mycelia were then removed and the blocks were dried at $80^{\circ} \mathrm{C}$ for $24 \mathrm{hrs}$ and weighed. Weight loss was determined as per the procedure described by Lekounougou et al. (2008) and expressed as percent loss.

Assessment of moisture in wood: Sterilized wood blocks were inoculated with the respective pathogens separately and incubated at $26 \pm 2^{\circ} \mathrm{C}$ for 60 days. After each incubation period, the percentage moisture absorbed by the wood samples was determined. The wet weight of the blocks were calculated after which they were oven-dried for $18 \mathrm{hrs}$ at $103^{\circ} \mathrm{C}$. The test blocks were allowed to cool and the moisture content was calculated. The proportional wood moisture content, u (oven dried), expressed as percentage was determined gravimetrically by measuring the wood mass before and after drying a wood sample at $103 \pm 2^{\circ} \mathrm{C}$ (Schmidt, 2007).

Assay of ligninolytic enzyme: Wood decay fungi were assessed for the production of ligninolytic enzymes, viz., laccase, lignin peroxidise (LiP) and manganese peroxidase (MnP). Liquid culture media was prepared as per the method suggested by Sayadi and Elouz (1995) and Dhouib et al. (2005). The media was inoculated with white-rot fungi $(D$. concentrica, G. lucidum, $L$. betulina, G. tsugae, T. versicolor and $S$. commune) separately and incubated for 10-12 days. The culture filtrate was centrifuged at $10,000 \mathrm{rpm}$ for $30 \mathrm{~min}$ at $4^{\circ} \mathrm{C}$ and assayed for enzyme activity.

Assay of laccase activity: Laccase activity was assayed using 2, 2'- azino-bis (3-ethylbenzothiazoline-6-sulfonic acid) (ABTS) (Sigma) as substrate (Rasera et al., 2009). The laccase reaction mixture contained $0.5 \mathrm{ml}$ of $0.45 \mathrm{mM} \mathrm{ABTS}, 1.2 \mathrm{ml}$ of $0.1 \mathrm{M}$ phosphate buffer ( $\mathrm{pH} \mathrm{6.0)}$ and $0.5 \mathrm{ml}$ of enzyme sample. The oxidation of substrate (ABTS) was read at $420 \mathrm{~nm}$.

Assay of lignin peroxidase (LiP): Lignin peroxidase activity was estimated by the method of Kang et al. (2009) with pyrogallol as substrate. The assay mixture contained $1 \mathrm{ml}$ of enzyme sample, $0.2 \mathrm{ml}$ of $0.1 \mathrm{M}$ pyrogallol, $2 \mathrm{ml}$ of $0.1 \mathrm{M}$ phosphate buffer $\mathrm{pH} 6.5$ with $0.1 \mathrm{ml}, 0.1 \mathrm{M}$ hydrogen peroxide. The enzyme activity was determined at $30 \mathrm{sec}$ interval for $5 \mathrm{~min}$ at $436 \mathrm{~nm}$ using molar extinction co-efficient of $2470 \mathrm{M}^{-1} \mathrm{~cm}^{-1}$

Assay of manganese peroxidase (MnP): $\mathrm{MnP}$ activity was assayed by the method of Warshii et al. (1992) with sodium malonate as substrate. The assay mixture contained $1 \mathrm{ml}$ of enzyme sample, $0.2 \mathrm{ml}$ of $1 \mathrm{mM} \mathrm{MnSO}_{4}$ in $0.05 \mathrm{M}$ sodium malonate, $0.2 \mathrm{ml}$ of $0.1 \mathrm{mM} \mathrm{H}_{2} \mathrm{O}_{2}$. The oxidation of sodium malonate was read at $270 \mathrm{~nm}\left(E_{270}=11.59 \mathrm{mM}^{-1} \mathrm{~cm}^{-1}\right)$. One unit of enzyme activity is defined as the amount of enzyme which produced $1 \mathrm{mM}$ of product $\mathrm{min}^{-1} \mathrm{ml}^{-1}$.

Statistical analysis: Mean differences of the treatment were evaluated with ANOVA using Duncan's multiple-range test at $5 \%$ significance (Gomez and Gomez, 1984). All the data were statistically analysed with IRRISTAT (version. 3/93, Biometrics unit, International Rice Research Institute) and consequently interpreted.

\section{Results and Discussion}

Wood decay fungi, viz., Daldinia concentrica, Ganoderma lucidum, Lenzites betulina, Ganoderma tsugae, Trametes versicolor and Schizophyllum commune, were isolated from infected logs of teak wood. The fungal pathogens identified belonged to Basidiomycota and Ascomycota based on their micro and morphological characters. The study on the colony character revealed that $D$. concentrica produced white felty colonies and black-grey coloration on the reverse side on PDA medium. Similarly, L. betulina exhibited dull white sparse mycelia and faster growth. S. commune produced white colony, pure white sparse mycelial growth and T. versicolor, G. lucidum and $G$.

Table 1: Weight loss percentage by wood decay fungi in different intervals using wood block method

\begin{tabular}{lllllll}
\hline \multicolumn{7}{c}{ Weight loss (\%) } \\
\hline $\begin{array}{l}\text { Duration } \\
\text { (days) }\end{array}$ & $\begin{array}{l}\text { Daldinia } \\
\text { concentric }\end{array}$ & $\begin{array}{l}\text { Ganoderma } \\
\text { lucidum }\end{array}$ & $\begin{array}{l}\text { Lenzites } \\
\text { betulina }\end{array}$ & $\begin{array}{l}\text { Ganoderma } \\
\text { tsugae }\end{array}$ & $\begin{array}{l}\text { Trametes } \\
\text { versicolor }\end{array}$ & $\begin{array}{l}\text { Schizophyllum } \\
\text { commune }\end{array}$ \\
\hline 15 & 3.50 & 2.90 & 3.70 & 2.50 & 3.90 & 2.00 \\
30 & 4.90 & 4.40 & 4.50 & 3.20 & 5.80 & 3.10 \\
45 & 7.50 & 6.60 & 6.50 & 5.50 & 7.50 & 4.90 \\
60 & 9.95 & 8.88 & 10.50 & 7.90 & 12.00 & 6.99 \\
Control (60 days) & 1.90 & 1.75 & 2.20 & 1.56 & 2.50 & 1.23 \\
SD & 0.096 & 0.064 & 0.09 & 0.04 & 0.05 & 0.096 \\
CD (0.05) & 0.21 & 0.13 & 0.21 & 0.10 & 0.13 & 0.21 \\
\hline
\end{tabular}

Values are mean of four replications. 
Table 2: Moisture content percentage at different intervals in wood decay fungi

\begin{tabular}{lllllll}
\hline \multicolumn{7}{c}{ Moisture content (\%) } \\
\hline $\begin{array}{l}\text { Duration } \\
\text { (days) }\end{array}$ & $\begin{array}{l}\text { Daldinia } \\
\text { concentric }\end{array}$ & $\begin{array}{l}\text { Ganoderma } \\
\text { lucidum }\end{array}$ & $\begin{array}{l}\text { Lenzites } \\
\text { betulina }\end{array}$ & $\begin{array}{l}\text { Ganoderma } \\
\text { tsugae }\end{array}$ & $\begin{array}{l}\text { Trametes } \\
\text { versicolor }\end{array}$ & $\begin{array}{l}\text { Schizophyllum } \\
\text { commune }\end{array}$ \\
\hline 15 & 22.20 & 27.78 & 30.00 & 23.34 & 32.50 & 18.85 \\
30 & 35.50 & 32.20 & 36.67 & 29.99 & 40.56 & 25.56 \\
45 & 41.11 & 38.89 & 42.23 & 36.67 & 46.67 & 32.23 \\
60 & 45.56 & 44.45 & 50.00 & 40.00 & 54.45 & 38.89 \\
Control & 17.78 & 25.50 & 28.50 & 21.00 & 29.00 & 15.50 \\
SD & 0.65 & 0.032 & 0.44 & 0.43 & 0.42 & 0.45 \\
CD (0.05) & 1.42 & 0.71 & 0.97 & 0.94 & 0.91 & 0.99 \\
\hline
\end{tabular}

Values are mean of four replicates

tsugae produced pure white dense mycelial growth. De Oliveira et al. (2019) found that T. versicolor is a wood degrading fungi associated with teak wood under storage condition. Similarly, Nagadesi et al. (2013) attributed L. stereoides, Lenzites sp., G. lucidum and Hexagonia apiaria as being responsible for decay of living and dead trees of teak hardwood. The wood degrading ability of isolated fungi was confirmed as evidenced by the percent weight loss of wood blocks. The results revealed that wood logs inoculated with $L$. betulina and $T$. versicolor recorded highest weight loss percentage of 10.50 and 12 , respectively, on $60^{\text {th }}$ day of incubation. This was followed by $D$. concentrica, which recorded the weight loss of $9.95 \%$. The wood logs colonized by $G$. lucidum, G. tsugae and S. commune were recorded with $8.88 \%$, $7.90 \%$ and $6.99 \%$ weight loss, respectively, compared to control. In general, weight loss in the wood blocks increased with increase in time (Table 1). Similar results were also observed by Tanesaka et al. (1993) who reported that wood blocks infected with Coriolus hirsutus, Panus rudis and Pycnoporus coccineus recorded 30\% weight loss but weight losses were $4 \%$ or less with $S$. commune in inoculated woods. The amount of degradation by the white-rot fungi was proportional to the length of the incubation period. It was observed that at very late stage of attack by wood decaying fungi, a loss of up to $97 \%$ in wood mass was found. (Schmidt, 2006). Emerhi (2008) also found that the weight loss varied from $1.5 \%$ to $48.1 \%$ in 30 trees inoculated with Coriolopsis polyzona. Pathogen inoculation on teak wood revealed that wood blocks inoculated with $T$. versicolor and L. betulina recorded the maximum moisture content of $54.45 \%$ and $50.00 \%$ after 60 days of inoculation. However, G. lucidum, G. tsugae and S. commune, recorded moisture content of $44.45 \%$, $40.00 \%$ and $38.89 \%$, respectively (Table 2 ).

The increase in moisture content may be influenced to a considerable extent of incubation by the test fungi. Several workers studied the change of moisture content in wood blocks of trees caused by white-rot fungi (De Groot, 1975; Reeb, 1995). Huckfeldt and Schmidt (2006) found that moisture content for freshly cut logs and undried lumber ranged from $45 \%$ to $200 \%$ by taking into account the optimum wood moisture content for several wood-rotting fungi that ranged from $34 \%$ to $210 \%$.
Similarly, Schmidt (2007) also observed that changes in the moisture content of wood block were influenced by the infection of wood decaying fungi. It suggested the role of different wood decay fungi on the changes of water content in teak wood. The white-rot fungi viz., Pseudo lagarobasidium acaciicola and Tricholoma giganteum had the potential of degradating hard wood which was identified by FTIR spectroscopy (Rudakiya and Gupte, 2019). Enzymatic assay revealed that the fungus $L$. betulina showed laccase, LiP and MnP enzyme activities to the extent of $0.60,0.056$ and $0.26 \mathrm{U} \mathrm{ml}^{-1}$. T. versicolor recorded the maximum enzyme activity whereas $S$. commune recorded a higher amount of laccase enzyme compared to other species (Table 3). Similar results were reported by Kinnunen et al. (2017), who found that higher secretion of laccase by the wood decay fungi leads to enhanced lignin degradation in woody biomass.

The rate of lignin degradation differed among species and in some cases showed no correlation with the level of laccase enzyme activity. Irbe et al. (2014) revealed that the fungus T. giganteum AGDR1 and P. acaciicola AGST3 showed higher laccase activities as compared to Tramates versicolor grown on Aspen, Alder and Birch wood. Laccase is one of the most important enzymes that plays an important role in lignin

Table 3: Changes in the enzyme activities in teak wood blocks inoculated with wood decay fungi

\begin{tabular}{llll}
\hline \multirow{2}{*}{ White-rot fungi } & \multicolumn{3}{c}{ Enzymes $\left(\mathrm{U} \mathrm{ml}^{-1}\right)$} \\
\cline { 2 - 4 } & Laccase & LiP & MnP \\
\hline Daldinia concentrica & 0.575 & 0.027 & 0.137 \\
Ganoderma lucidum & 0.079 & 0.008 & 0.051 \\
Lenzites betulina & 0.600 & 0.056 & 0.260 \\
Ganoderma tsugae & 0.073 & 0.0070 & 0.048 \\
Trametes versicolor & 0.710 & 0.068 & 0.251 \\
Schizophyllum commune & 0.456 & 0.019 & 0.095 \\
SD & 0.41 & 0.05 & 0.09 \\
CD (0.05) & 0.82 & 0.63 & 0.91 \\
\hline
\end{tabular}

Values are mean of four replicates 
degradation (Call and Mucke, 1997). Furthermore, more ligninolytic enzyme activity is directly correlated with the per cent of weight loss and may play a key role in lignin degradation. Degradation of lignin seems to occur gradually with the increase in incubation period but the peak of laccase enzyme activity was reached much earlier. It is suggested that the wooddecaying course of the fungi is not a simple metabolic reaction. A complicated relationship exists between the enzyme activity and wood decaying ability of the fungi, where many enzymes are involved (Moredo et al., 2003; Liu et al., 2009). The ligninolytic enzyme from $\mathrm{G}$. lucidum contains a pair of 36 ligninolytic oxidoreductases, including eight class-II peroxidises, 13 laccases, one cellobiose dehydrogenase, nine copper radical oxidases, three aryl-alcohol oxidases, one benzoquinone reductase and one alcohol oxidase (Chen et al., 2012).

This study suggests that production capability of wood decay fungi is responsible for changes in weight loss and moisture content. The present preliminary study provides information on the degrading enzymes secreted by wood decay fungi and their role in degradation of teak wood under storage. These finding may be useful for scientists and industrialists to formulate suitable management strategies to avoid economic loss during critical period of storage.

\section{Acknowledgments}

The authors duly acknowledge the Forest College and Research Institute, Mettupakayam and Department of Plant Pathology, Tamil Nadu Agricultural University, Coimbatore for providing laboratory facilities.

\section{Add-on Information}

Authors' contribution: A. Sudha: Conceptualized the study and conducted the experiments related to this study, G. Thiribhuvanamala: Conducted the experiments related to this study, S. Rajamanickam: Conducted the experiments related to this study and involved in the writeup.

Research content: The research content of manuscript is original and has not been published elsewhere.

\section{Ethical approval: Not applicable}

Conflict of interest: The authors declare that there is no conflict of interest.

\section{Data from other sources: Not applicable}

Consent to publish: : All authors agree to publish the paper in Journal of Environmental Biology.

\section{References}

Akhtar, M., M.C. Attridge, G.C. Myers and R.A. Blanchette: Biomechanical pulping of loblolly pine chips with selected white-rot fungi. Holzforschung, 47, 36-40 (1993).

Amadi, J.E. and Y.A Saka: Isolation and identification of fungi associated with teak (Tectona grandis L.) seedlings at the University of llorin teak plantation, Kwara State, Nigeria. NISEB J., 11, 189-195 (2011).

Call, H.P. and I. Mucke: History, overview and applications of mediated ligninolytic systems, especially laccase-mediator-systems (Lignozym(R)-process). J. Biotechnol., 53, 163-202 (1997).

Chen, Z.W., C.Vignaud, A. Jaafar, B. Levy, F. Gueritte, D. Guenard, F. Lederer and F.S. Mathews: High resolution crystal structure of rat long chain hydroxy acid oxidase in complex with the inhibitor 4carboxy-5-[(4-chlorophenyl) sulfanyl]-1,2,3-thiadiazole. Implications for inhibitor specificity and drug design. Biochimie, 94, 1172-1179 (2012)

Couto, S.R.: Dye removal by immobilized fungi. Biotechnol. Adv., 27, 227-235 (2009).

De Groot, R.C.: Decay fungus, light, moisture interactions. Wood Sci., 7, 219-222 (1975).

De Oliveira, W.C., B.L.C. Pereira, L.S.D. Assis Goes, M. T.Quintilhan, A.C. Oliveira and R. Mora,: Deterioration of teak wood in accelerated decay test. Floresta eAmbiente, 26, e20170360 (2019).

Dhouib, A., M. Hamza and H. Zouari: Screening for ligninolytic enzyme production by diverse fungi from Tunisia. World J. Microbiol. Biotechnol., 21, 1415-1423 (2005).

Emerhi, E.A., B.A. Ekeke and B.A. Oyebade: Biodegrading effects of some rot fungi on Pinus. Afr. J. Biotechnol., 7, 512-1515 (2008).

Gahlout, M., D.M. Rudakiya and A. Gupte: Laccase-conjugated amino functionalized nanosilica for efficient degradation of Reactive violet 1 dye. Int. Nano Lett., 7, 195-208 (2017)

Gomez, K.A. and A.A. Gomez: Statistical Procedure for Agricultural Research. John Wiley and Sons, New York, 680 p. (1984)

Huckfeldt, T. and O. Schmidt: Identification key for European strandforming house-rot fungi. Mycologist., 20, 42-56 (2006)

Irbe, L., L. Urbonas and D. Heinz: Coal fly ash activation-comparison of isothermal calorimetric data and mortar strength. Thermochim. Acta., 659, 151-156 (2018)

Kang, Y.M., M.L. Prewitt and S.V. Diehl: Proteomics for biodeterioration of wood (Pinus taeda L.): challenging analysis by 2-D PAGE and MALDI-TOF/TOF/MS. Int. Biodeter. Biodegr., 63,1036-1044, (2009).

Kinnunen A, P. Maijala, P. Jarvinen and A. Hatakka: Improved efficiency in screening for lignin-modifying peroxidases and laccases of basidiomycetes. Curr. Biotechnol., 6,105-115 (2017).

Kirk, T.K, R.R. Burgess and J.W. Koning: Use of fungi in pulping wood:An overview of biopulping research. In: Frontiers in Industrial Mycology. (Ed.: G. Leatham). New York, Routledge, Chapman and Hall, p. 99 (1992a).

Kirk, T.K, R.R. Burgess, J.W. Koning, R.T. Lamar and J.A. Glaser: The potential of white-rot fungi in bioremediation. In: Biotechnology and Environmental Ecience (Ed.: S. Mongkolsuk). New York, Plenum Press, pp. 131-138 (1992b).

Lekounougou, S., M. Petrissans, J.P. Jacquot, E. Gelhaye and P. Gerardin: Effect of heat treatment on extracellular enzymatic activities involved in beech wood degradation by Trametes versicolor. Wood Sci. Technol., 43, 331-341 (2008).

Liu, B., Z. Lei and Z. Huang: Surface-treated activated carbon for removal of aromatic compounds from water. Chem. Eng. Technol., $32,763-770$ (2009).

Manavalan, T., A. Manavalan and K. Heese: Characterization of lignocellulolytic enzymes from white-rot fungi. Curr. Microbiol., 70 , 485-498 (2015)

Marcot, B.G.: A review of the role of fungi in wood decay of forest 
Ecosystems, SDA, PNW-RN-575,p 32 (2017).

Matthews, E.: Understanding the FRA 2000. World Resources Institute Forest Briefing No. 1, Washington DC. In: World Resources Institute, p.11 (2001).

Mendonça R. T., J.F. Jara, V. Gonzalez, J.P. Elissetche and J. Freer: Evaluation of the white-rot fungi Ganoderma australe and Ceriporiopsis subvermispora in biotechnological applications. J. Ind. Microbiol. Biotechnol., 35, 1323-1330 (2008)

Moredo, N., M. Lorenzo and A. Dominguez: Enhanced ligninolytic enzyme production and degrading capability of Phanerochaete chrysosporium and Trametes versicolor. World J. Microbiol. Biotechnol., 19, 665-669 (2003).

Nagadesi, P.K., A. Arya and S. Albert: Delignification pattern of wood decay by white rot fungi in teak (Tectona grandis L. f.). J. Indian Acad. Wood Sci., 10, 1-8 (2013).

Natrajan, K. and K. Kolandavelu: Resupinate Aphyllophorales of Tamil Nadu, India. Centre for Advance Study in Botany, University of Madras, pp.133 (1998)

Patrick, F., G. Mtui, A.M. Mshandete and A. Kivaisi: Optimized production of lignin peroxidases, manganese peroxidases and laccase in submerged cultures of Trametes trogii using various growth media compositions. Tanz. J. Sci., 36,1-18(2010)

Rangaswami, G.: An agar blocks technique for isolating soil micro organisms with special reference to Pythiaceous fungi. Sci. Cult., $24,85(1958)$

Rasera K, J. Ferla, A. Dillon, R .Riveiros and M. Zeni: Immobilization of laccase from Pleurotus sajor-caju in polyamide membranes. Desalination, 245, 657-661 (2009)

Reeb, J.E.: Wood and moisture relationships. Oregon State University Bulletin EM8600, (1995).
Rudakiya, D. M. and A. Gupte: Assessment of white rot fungus mediated hardwood degradation by FTIR spectroscopy and multivariate analysis. J. Microbiol. Methods, 157, 123-130 (2019).

Ryu, W.Y., M.Y. Jang and M.H. Cho: The selective visualization of lignin peroxidase, manganese peroxidase and laccase, produced by white rot fungi on solid media. Biotechnol. Bioprocess Eng., 8, 130$134(2003)$

Sayadi, S. and R. Ellouz: Roles of lignin peroxidase and manganese peroxidase from Phanearochaete chrysosporium in the decolorization of olive mill wastewaters. Appl. Environ. Microbiol., 61, 1098-1103 (1995)

Schmidt, O.: Indoor wood-decay basidiomycetes: damage, causal fungi, physiology, identification and characterization, prevention and control. Mycol. Prog., 6, 261-279 (2007)

Schmidt, O.: Wood and Tree Fungi. Biology, Damage. Protection, and Use. Springer, Berlin Heidelberg New York., Germany, pp. 348 (2006).

Stalpers, J. A.: Identification of wood-inhabiting Aphyllophorales in pure culture. Stud. Mycol., 16, p. 248 (1978)

Tanesaka, E., H. Masuda and K. Kinugawa: Wood degrading ability of basidiomycetes that are wood decomposers, litter decomposers or mycorrhizal symbionts. Mycologia, 85, 347-354 (1993)

Warshii, H., K. Valli and M.H. Gold: Manganese(II) oxidation by manganese peroxidase from the basidiomycete, Phanerochaete chrysosporium. Kinetic mechanism and role of chelators. J. Biol. Chem., 267, 23688-23695 (1992).

Xu, P., Y. Leng, G. Zeng and D. Huang: Cadmium induced oxalic acid secretion and its role in metal uptake and detoxification mechanisms in Phanerochaete chrysosporium. Appl. Micrbiol. Biot., 99, 435-443 (2015). 